Jolanta Dyrda

Ateneum - Szkoła Wyższa w Gdańsku

\title{
Edukacyjna presja norm. Krytyczne uwagi na marginesie pracy z dziećmi ze specjalnymi potrzebami edukacyjnymi
}

Celem prezentowanego przeze mnie tekstu jest ukazanie złożonej problematyki specjalnych potrzeb edukacyjnych, zarówno w obszarze stosowanej terminologii, jak i form oraz metod dostosowania wymagań edukacyjnych szkoły wobec uczniów $\mathrm{z}$ takimi potrzebami. Znaczący $\mathrm{z}$ tej perspektywy wydaje się dylemat organizowania formalnych ram edukacji sprzyjających edukacji lub utrudniających ją tym uczniom. Przeciwstawiając indywidualizacji procesu kształcenia normalizowanie wymagań, jedynie pozornie rozwiązujemy problem edukacji dla wszystkich, z uwzględnieniem ich możliwości i trudności.

Gdy przed parlamentem brytyjskim w 1978 roku Mary Warnock przedstawiała raport pracującej pod jej kierunkiem przez trzy lata komisji, nikt ze słuchaczy prawdopodobnie nie przypuszczał, że użyte w Report of the Commitee Enquiry into the Education of Handicapped Children and Young People (Olechowska 2016: 24) określenie „specjalne potrzeby edukacyjne” odegra w przyszłości tak istotną rolę w edukacji. Politycy i działacze oświatowi zdali sobie sprawę, że edukacja nie uwzględnia zróżnicowania potrzeb i możliwości znacznej grupy uczniów. Wkrótce też pojawiły się zarówno kontrowersje definicyjne, terminologiczne, jak i pytania czy wątpliwości co do przyczyn formułowania poszczególnych kategorii specjalnych potrzeb, różniące podejścia badaczy i praktyków edukacji. Aktualna dyskusja nad kształtem edukacji uczniów z orzeczeniem o niepełnosprawności ukazuje, jak trudno o jednoznaczne rozumienie możliwości i form realizacji edukacji szkolnej oraz dostosowania wymagań edukacyjnych do potrzeb uczniów ze specjalnymi potrzebami edukacyjnymi.

Terminem „specjalnych potrzeb edukacyjnych” określa się takie potrzeby, które wymagają dostosowania warunków lokalowych i dydaktycznych placówek edukacyjnych do indywidualnych możliwości rozwojowych i poznawczych uczniów. Zatem zaspokojenie specjalnych potrzeb edukacyjnych ucznia to umożliwienie mu, pomimo jego trudności manifestujących się w różny sposób, korzystania ze szkoły 
ogólnodostępnej, z jednoczesnym dostosowaniem wymagań do możliwości tego ucznia (Chrzanowska 2015: 423). Określenie „specjalne potrzeby edukacyjne” było odpowiedzią na rosnącą potrzebę indywidualizacji kształcenia, zatem raport Warnock przedstawiający głównie możliwości szerokiego włączenia uczniów niepełnosprawnych do zwykłych publicznych szkół stał się tylko pretekstem do szerokiej dyskusji nad innymi grupami uczniów ze specjalnymi potrzebami edukacyjnymi. Od 7 do 10 czerwca 1994 roku ponad 300 uczestników konferencji w hiszpańskiej Salamance dyskutowało nad ideą edukacji dla wszystkich. Podpisana przez przedstawicieli 92 państw (w tym także Polski) Deklaracja $z$ Salamanki oraz wytyczne dla działań w zakresie specjalnych potrzeb edukacyjnych (dalej: deklaracja z Salamanki) otworzyła perspektywy edukacji dla wszystkich z uwzględnieniem możliwości i potrzeb uczniów mających szczególne potrzeby edukacyjne. Przewodnią zasadą wytycznych jest rekomendacja objęcia edukacją wszystkich dzieci bez względu na ich warunki fizyczne, intelektualne, socjalne, językowe i inne (deklaracja $\mathrm{z}$ Salamanki).

W Polsce w 1998 roku pojawił się dokument MEN (Reforma systemu kształcenia uczniów ze specjalnymi potrzebami edukacyjnymi), który z pewnym opóźnieniem realizował podpisaną wcześniej deklarację z Salamanki. Obowiązywała ustawa z dnia 7 września 1991 r. o systemie oświaty (tekst jedn.: Dz. U. z 2016 r., poz. 1943) oraz rozporządzenia. Najistotniejsze znaczenie dla edukacji uczniów ze specjalnymi potrzebami edukacyjnymi ma obecnie obowiązujące rozporządzenie Ministra Edukacji Narodowej z dnia 30 kwietnia 2013 r. w sprawie udzielania pomocy psychologiczno-pedagogicznej $\mathrm{w}$ publicznych przedszkolach, szkołach i placówkach (Dz. U. z 2017 r., poz. 1643).

W rozporządzeniu tym wymieniono kategorie uczniów ze specjalnymi potrzebami edukacyjnymi, które obejmują uczniów:

- z niepełnosprawnością;

- $\quad \mathrm{z}$ niedostosowaniem społecznym;

- z zagrożeniem niedostosowaniem społecznym;

- ze szczególnymi uzdolnieniami;

- ze specyficznymi trudnościami w uczeniu się;

- z zaburzeniami komunikacji językowej;

- $\quad$ z chorobami przewlekłymi;

- w sytuacjach kryzysowych lub traumatycznych;

- $\quad \mathrm{z}$ niepowodzeniami edukacyjnymi;

- $\quad \mathrm{z}$ zaniedbanych środowisk związanych $\mathrm{z}$ sytuacją bytową ucznia $\mathrm{i}$ jego rodziny, sposobem spędzania czasu wolnego i kontaktami środowiskowymi;

- $\quad \mathrm{z}$ trudnościami adaptacyjnymi związanymi z różnicami kulturowymi lub ze zmianą środowiska edukacyjnego, w tym związanych $\mathrm{z}$ wcześniejszym kształceniem za granicą.

Wszystkie te kategorie uczniów ze specjalnymi potrzebami powinny być objęte pomocą psychologiczno-pedagogiczną udzielaną $\mathrm{w}$ przedszkolu, szkole i placówce edukacyjnej. Pomoc taka może być udzielona także rodzicom uczniów 
i nauczycielom. W tym obszarze polega ona na wspieraniu rodziców i nauczycieli w rozwiązywaniu problemów wychowawczych i dydaktycznych oraz rozwijaniu ich umiejętności wychowawczych w celu zwiększania efektywności pomocy psychologiczno-pedagogicznej dla uczniów.

W świetle dokumentów międzynarodowych i rozporządzeń Ministra Edukacji sytuacja uczniów ze specjalnymi potrzebami edukacyjnymi wydaje się kształtować korzystnie, obejmując szeroką grupę różnych trudności i wskazując na sposoby i formy udzielania pomocy terapeutycznej.

Jednak w praktyce szkolnej zauważa się wiele nieprawidłowości, głównie za sprawą nieefektywnego wsparcia systemowego (Chrzanowska 2015: 425). Na podstawie danych zawartych w Systemie Informacji Oświatowej w Polsce w roku szkolnym 2012/2013 było 158748 uczniów niepełnosprawnych we wszystkich kategoriach niepełnosprawności z orzeczeniami o specjalnych potrzebach edukacyjnych, co stanowi 2,68\% wszystkich dzieci w placówkach edukacyjnych. Podobne dane odnotowano w Wielkiej Brytanii, gdzie odsetek ten wyniósł 2,8\%. Wydaje się jednak, na podstawie badań prowadzonych w latach osiemdziesiątych i dziewięćdziesiątych XX wieku, że wiele dzieci nie posiada orzeczeń o specjalnych potrzebach edukacyjnych. Badania wskazywały na rzeczywisty odsetek tych uczniów w granicach 5-10\% (Chrzanowska 2015: 431). Oprócz uczniów z niepełnosprawnością warto także zwrócić uwagę na specyfikę innych grup uczniów wymagających wsparcia w edukacji szkolnej, niektórzy z nich mają specjalne potrzeby edukacyjne obejmujące kilka kategorii ujętych w rozporządzeniu MEN, podczas gdy trudności innych dzieci zawierają się w jednej, np. specyficznych trudnościach w uczeniu się, dotyczących trudności o charakterze dyslektycznym. W praktyce edukacyjnej obejmującej organizowanie pomocy i dostosowanie kształcenia do potrzeb i możliwości uczniów generuje to trudności związane z finansowaniem wsparcia, zwłaszcza w sytuacji konieczności jego organizowania dla dzieci z wieloma trudnościami w obszarze uczenia się. Najpełniej sytuację w tym zakresie ilustrują badania przeprowadzone w Polsce w ramach monitoringu Helsińskiej Fundacji Praw Człowieka (Prawo do edukacji dzieci o specjalnych potrzebach edukacyjnych) przeprowadzonego w 2010 roku. Badaniem objęto 121 szkół w 61 gminach. Szkoły podstawowe stanowiły $61 \mathrm{z}$ nich, zaś gimnazjalne - 60 . Prowadzone badania koncentrowały się wokół problemu realizacji przepisów prawa dotyczących kształcenia uczniów ze specjalnymi potrzebami edukacyjnymi (Ciechanowska, Chmielewska, Czyż, Kołodziej za: Chrzanowska 2015). Z opinii dyrektorów szkół wynikało, że największy odsetek uczniów ze specjalnymi potrzebami edukacyjnymi w badanych szkołach stanowią uczniowie ze specyficznymi trudnościami w uczeniu się. Wydane w poradniach psychologiczno-pedagogicznych opinie stwierdzające takie trudności stanowiły w badanych szkołach podstawowych 14,3\% wszystkich uczniów, a w objętych badaniami gimnazjach - 15,2\%. Na podobny odsetek uczniów z trudnościami o charakterze dyslektycznym (uczniowie ze specyficznymi trudnościami w uczeniu się) zwracają uwagę wieloletni badacze zagadnienia, w literaturze z tego obszaru podobnie przedstawia się występowanie tego typu trudności w zakresie 
10-15\% uczniów, z 4\% uczniów o nasilonych objawach trudności (Bogdanowicz, Adryjanek 2004: 23). Interesującym wnioskiem sformułowanym w oparciu o analizy materiału z powyższych badań była forma pomocy kierowanej w szkołach do uczniów ze specyficznymi trudnościami w uczeniu się. Najczęściej stosowany rodzaj wsparcia stanowiło obniżenie wymagań edukacyjnych wobec tych uczniów. Nieobecność innych form pomocy, indywidualizacji nauczania czy prowadzenia zajęć terapii pedagogicznej $\mathrm{w}$ zakresie pracy $\mathrm{z}$ uczniami ze specyficznymi trudnościami w uczeniu się dyrektorzy szkół wyjaśniali trudnościami organizacyjnymi lub brakiem środków finansowych. Zwłaszcza trudności organizacyjne były przez dyrektorów objętych badaniem szkół szeroko uzasadniane. Należą do nich: konieczność organizowania dodatkowego dojazdu do szkół na zajęcia dla dzieci mieszkających $\mathrm{w}$ znacznej odległości, brak zainteresowania rodziców dodatkowymi zajęciami, niska efektywność zajęć, brak wykwalifikowanych specjalistów w zakresie prowadzenia specjalistycznej terapii specyficznych trudności w uczeniu się (Ciechanowska, Chmielewska, Czyż, Kołodziej za: Chrzanowska 2015: 437).

Kolejną grupę uczniów ze specjalnymi potrzebami edukacyjnymi stanowią uczniowie ze szczególnymi uzdolnieniami. Nie jest to kategoria rozłączna, wśród uczniów zdolnych są zarówno uczniowie ze specyficznymi potrzebami edukacyjnymi, niepełnosprawni także $\mathrm{z}$ niepełnosprawnością intelektualną, oraz reprezentujący inne grupy uczniów $\mathrm{z}$ trudnościami. Zadanie rozwijania potencjału tych uczniów w edukacji szkolnej nie jest realizowane, choć wydawać się może, że uczniowie ci stanowią grupę, z którą nauczyciele osiągają sukcesy dydaktyczne. Wobec tych uczniów Sylvia Rimm stosuje określenie Syndromu Nieadekwatnych Osiągnięć (Rimm 1994). Według autorki uczniowie zdolni to często dzieci nieodnoszące sukcesów szkolnych. Nastawiona na typ zdolności poznawczych szkoła preferuje te zdolności, które umożliwiają przyswajanie znacznych ilości wiedzy, a w efekcie przygotowanie zdolnego ucznia do olimpiady przedmiotowej lub konkursu. Pozostałe uzdolnienia: artystyczne, aktorskie, sportowe, społeczne nie są cenione w takim stopniu, a zauważane są jedynie przez nauczycieli przedmiotów artystycznych o tradycyjnie niższych notowaniach w hierarchii szkolnej. Osiąganiu sukcesów edukacyjnych przez uczniów uzdolnionych nie sprzyja także pojęcie „dobrego ucznia” definiowane przez szkołę jako tego, który osiąga dobre oceny ze wszystkich przedmiotów. Rywalizacja edukacyjna nie służy rozwijaniu poczucia sukcesu u uczniów, którzy są wybitnie zdolni w wybiórczych obszarach zdolności. W środowisku szkolnym jest zbyt mało okazji odnoszenia sukcesów, zbyt wiele sytuacji, w których można odczuć porażki (Rimm 1994).

Odrębne zagadnienie $\mathrm{w}$ tym obszarze stanowi sytuacja edukacyjna ucznia niepełnosprawnego ze szczególnymi uzdolnieniami, stosunkowo rzadko analizowana w obszarze literatury na temat zdolności. Uzdolnieni z różnymi rodzajami niepełnosprawności to osoby mogące osiągnąć sukcesy mimo upośledzeń, takich jak: uszkodzenie wzroku, słuchu, wady ortopedyczne, trudności w uczeniu się o podłożu intelektualnym. Uzdolnieni z niepełnosprawnością potrzebują edukacji uwzględniającej ich zdolności, a zarazem biorącej pod uwagę stopień i rodzaj 
niepełnosprawności (Klinkosz 2004: 94). Na skutek wcześniej realizowanego, specjalnego i odrębnego sposobu edukacji osób niepełnosprawnych koncentrowano się raczej na ich niepełnosprawności i przygotowaniu do możliwie pełnej adaptacji do samodzielności, nie zaś na ich możliwościach i zdolnościach. W kontekście powyższych analiz wybranych kategorii uczniów ze specjalnymi potrzebami edukacyjnymi pojawia się zagadnienie dotyczące funkcjonowania szkoły jako instytucji edukacyjnej, jej roli, jawnych i ukrytych procedur oraz efektów działania.

$\mathrm{W}$ jawnych procedurach postrzega się szkołę jako formę działania zorganizowanego, skoncentrowaną na osiąganiu celów i określaniu środków do ich realizacji (Dyrda 2009).

Do niejawnych reguł porządkujących funkcjonowanie uczniów w instytucjach edukacyjnych należą normy, które regulują określanie pozycji ucznia w systemie. Pojęcie normy bywa różnie definiowane w literaturze, począwszy od etymologii słowa oznaczającego pierwotnie kątownicę - „przyrząd do wyznaczania w budownictwie kąta prostego"; norma w takim ujęciu oznacza to, co mieści się w jej ramionach, zawartość zależną od przyjęcia jednego z uznanych sposobów jej rozumienia (Dyrda 2009):

- spotykaną u większości przedstawicieli danego gatunku;

- mieszczącą się w wartości przeciętnej jakiejś mierzalnej cechy;

- zgodność z regułą, prawidłowość.

Przy czym pierwsze określenie normy wyodrębnia jej biologiczny charakter, wskazując na zewnętrzną i wewnętrzną zgodność budowy, wyglądu i funkcji narządów zgodnych ze spotykanymi powszechnie w populacji. Odmienność w tym obszarze ma najbardziej społecznie zauważalny charakter. Obecne w starożytności i średniowieczu postawy dyskryminacji, izolacji, a nawet skazywania na śmierć osób niepełnosprawnych wskazują na brak społecznego akceptowania w historii odstępstw od norm biologicznych. Także wiek XIX ze swoim naukowym podejściem do klasyfikowania, opisywania i wyodrębniania różnic rozwojowych organizował segregację ze względu na niepełnosprawności rozwojowe, umieszczając uczniów nimi dotkniętych (nie odbierając im jednak prawa do edukacji) w izolowanych ośrodkach realizujących odrębne formy kształcenia w zakresie metod i treści. Praktycznie miało to chronić niepełnosprawnych przed otwartym, „sprawnym” społeczeństwem, ale też chronić społeczeństwo przed świadomością istnienia różnych odmienności biologicznych. Dopiero w drugiej połowie wieku XX zmieniają się postawy społeczne, co jest spowodowane humanizacją życia i celowymi działaniami instytucji (Obuchowska 2005).

Drugi z obszarów interpretowania normy wskazuje na jej rozumienie w zakresie mierzalnych cech, co w obszarach edukacyjnych dotyczy głównie opierania się na pomiarach inteligencji oraz wskazywaniu wartości zawartych w zakresie normy intelektualnej. Już w drugiej połowie XIX wieku Francis Galton, stosując krzywą rozkładu normalnego Gaussa, przedstawiał obszar zdolności umysłowych człowieka, wskazując za pomocą odchylenia standardowego przedział uważany za normę możliwości intelektualnych. Zapoczątkowana przez niego psychometryczna 
metoda jest stosowana $\mathrm{w}$ określaniu poziomu inteligencji do czasów obecnych. Funkcjonującym współcześnie testom ich krytycy zarzucają sprzede wszystkim (Gardner, Kornhaber, Wake 2001):

- konwergencyjny charakter zadań, co oznacza, że badany ma znaleźć odpowiedź z góry ustaloną, służącą wyłącznie do pomiaru inteligencji i zdolności;

- podejście normalizacyjne, odnoszące się do statystycznego układu odniesienia, wyniki badań inteligencji są oceniane na tle wyników grupy, co stanowi próbę normalizacyjną;

- ujęcie ilościowe, co podkreślać ma obiektywny charakter badań, zaś wynik podawany jest zawsze jako liczba;

- standaryzację, której istotę stanowi ujednolicenie zadań, procedur i sposobu oceny poziomu inteligencji;

- stosowanie tabel norm uwzględniających poziom wieku badanych oraz uaktualnienia kulturowe i językowe, nieuwzględniających jednocześnie różnic w statusie kulturowym i językowym badanych.

Znaczenie trzeciego z obszarów nadawanego normie jest najszerzej reprezentowane w edukacji, jednocześnie dając możliwość nadużywania stanowionych w oparciu o niego zasad i regulaminów. Zgodność z regułą zakłada bowiem zgodność z każdą ustanowioną regułą w obszarze edukacji szkolnej, która tym samym staje się wymagalna. Przykłady w tym zakresie stanowią regulaminy szkolne, kryteria oceniania, testy zewnętrzne, jak też określanie, kto i w jakim zakresie jest w stanie sprostać tak sformułowanym oczekiwaniom. W związku z podejmowanym przeze mnie zagadnieniem specjalnych potrzeb edukacyjnych można postawić ryzykowną tezę, że w rozumieniu tak określanej normy obszar ten określa jednocześnie tych, którzy nie są w stanie w pełni realizować określanych przez szkołę oczekiwań co do sposobu uczestniczenia w organizowanej przez nią edukacji. Uwagę na takie stanowisko zwraca także Małgorzata Jacyno, wskazując, że „Nowe «odchylenia» nie mają już, co łatwo zauważyć, tej samej mocy wykluczania z procesu edukacyjnego i nie są wyrokami na całe życie, [...] ale stanowią raczej «specyficzną niesprawność», która nie determinuje ostatecznej oceny i nie rozstrzyga o porażce w szkole [...]" (Jacyno2007: 162). Uwzględniając przedstawione rozumienia norm, można wyodrębnić ich obszary sankcjonowane przez instytucjonalnie rozumianą szkołę (Dyrda 2009: 634).

Wśród obszarów normy rozumianej w tym sensie szczególne znaczenie mają normy:

- biologiczne - określają minimalny poziom zdrowia, sprawności, inteligencji, artykulacji mowy;

- intelektualne - określają zdolność do posługiwania się wymaganymi sposobami myślenia (logicznym, abstrakcyjnym, racjonalnym), nabywania umiejętności czytania, pisania, liczenia;

- społeczne - określają wymagany poziom zdolności komunikacyjnych, zachowania, wymagań osobowościowych niezbędnych do realizacji zadań społecznych; 
- posiadanych wiadomości - określają poziom wiedzy szkolnej wymaganej na danym etapie edukacji.

W ramach instytucji zostają określone jednoznaczne procedury interpretacyjne, stanowiące niezmienne reguły definiujące poprawne czy normalne zachowania oraz precyzujące pożądane ich efekty (Dyrda 2009: 629). W swej istocie normy zawierają także pewien aspekt konieczności ich respektowania, nakaz podporządkowania się ich wymogom. Chociaż większość z nich ma charakter niejawny, niesprecyzowany, to ich realizowanie ujmuje się powszechnie jako gwarancję szkolnego sukcesu ucznia. Krytyka normatywnego podejścia instytucji edukacyjnych nasuwa odmienny kierunek poszukiwania organizacyjnych ram, sprzyjających uczeniu się dzieci ze specjalnymi potrzebami edukacyjnymi. Kierunkiem tym jest, sięgająca w pedagogice początku XX wieku, indywidualizacja nauczania. Indywidualizacja wydaje się być sprzyjającym rozwojowi dziecka procesem, umożliwiającym dostosowanie oddziaływań edukacyjnych szkoły zarówno do jego potencjału rozwojowego, jak i odczuwanych przez ucznia trudności. Przeciwstawia się to określenie pojęciu ujednolicania, standaryzacji oczekiwań czy bezwzględnemu sprostaniu wymaganiom norm. Odnieść się do ucznia indywidualnie to w rozumieniu nauczycielskim wyłonić go z uporządkowanej zbiorowości i anonimowości. Jest przeciwwagą dla przywoływanego przez Michela Foucaulta opisu dnia $\mathrm{w}$ osiemnastowiecznym sierocińcu przedstawionym jako miejsce anonimowości i porządku: „Znaleźliśmy wszystkich uczniów w szyku bojowym, zastygłych nieruchomo i w absolutnej ciszy" (Foucault 2009: 174).

Przedstawiony obraz budzi nieustanną tęsknotę, mam nadzieję, nielicznych, także współczesnych nauczycieli, dla których uczeń jest anonimowym wykonawcą poleceń, w skrajnych przypadkach wywoływanym do odpowiedzi jako numer z listy w dzienniku. Zatem wydaje się oczywiste, że, wybierając model edukacji oparty na władzy nad anonimową zbiorowością uczniów, dążąc do ich ujednolicenia, nauczyciel odwołuje się do archaicznego rozumienia modelu szkoły. Indywidualizacja utożsamiana $\mathrm{z}$ uwzględnianiem jednostkowych możliwości ucznia, a zarazem „pochylaniem” się nad jego ograniczeniami w ogólnych rozważaniach pedagogicznych wyraźnie sytuuje się jako stan powszechnie pożądany (Rimm 1994: 127; Robinson 2010). Jednak także tak naiwne postrzeganie indywidualizmu w działaniach edukacyjnych może prowadzić do przeniesienia na ucznia odpowiedzialności za jego porażki edukacyjne, skoro szkoła dołożyła wszelkich starań, aby ułatwić jego edukację przez uwzględnienie specjalnych potrzeb. „Obserwowane «odchylenia» od normy i rejestrowane «braki» składają się ostatecznie na indywidualną i niepowtarzalną historię życia jednostki. W myśl tej logiki indywidualizować się to poszukiwać siebie wśród tych, którzy zostali najszczegółowiej opisani, najwnikliwiej przebadani” (Jacyno 2007: 159). Tak rozumiane określenie umieszcza indywidualizację jako proces z jednej strony marginalizujący przez diagnozę, a z drugiej wyłączający ze wspólnoty „nieopisanych”, przez co także wykluczający tych uczniów ze standardowych działań i oczekiwań szkoły kierowanych do pozostałych. 
Uwzględniając stosowane kryteria oceny pracy szkoły oparte na wskaźnikach Edukacyjnej Wartości Dodanej, porównując za pomocą kalkulatora EWD szkoły jednego typu pomiędzy sobą (gimnazja, technika, licea ogólnokształcące) na podstawie wyników egzaminów zewnętrznych, w istocie rankinguje się pozycje szkół, stosując statystyczne metody (www.cke.edu.pl/wskaźniki-ewd/). W tej sytuacji postrzega się uczniów ze specjalnymi potrzebami jako obniżających wyniki egzaminów zewnętrznych, a nauczyciele przedmiotów objętych egzaminami próbują namawiać tych uczniów do zaniechania przystępowania do matury.

Trudność rozstrzygnięcia dylematu normalizacja czy indywidualizacja w edukacji polega na tym, że zarówno sankcjonujący wymiar norm przedstawionych w poprzedniej części, jak i indywidualizowanie uczniów ze specjalnymi potrzebami edukacyjnymi przyczynia się, wbrew intencjom twórców i propagatorów rozwiązania, do wyodrębniania i wyłączania ich z głównego nurtu edukacyjnego szkoły. Dylemat ma więc charakter przewrotny, indywidualizacja uczniów może stać się jednocześnie normą nowego typu wobec możliwości takiego postrzegania indywidualizacji, które, uwzględniając opisanie jednostki w kategoriach jej potrzeb i trudności edukacyjnych, jednocześnie ją alienują przez szczegółową charakterystykę jej deficytów i braków, wykluczając tym samym ze społeczności uczniów, którzy takiej procedurze nie podlegają, mieszcząc się w normach i regułach zawartych w oczekiwaniach szkoły w jej instytucjonalnym wymiarze. „W pewnym sensie władza normalizująca wymusza homogenizację [...], pozwalając mierzyć odstępstwa od normy, określając poziom, ustalając granice - indywidualizuje” (Ball 1999: 35).

Przypisując znaczenie procesom indywidualizacji jako naznaczenia jednostki za pomocą diagnozy, w zasadzie odwołujemy się do poziomu jej biologicznej odmienności. Niepełnosprawność zmysłowa, ruchowa czy intelektualna mają swój medyczny i edukacyjny obraz. Diagnoza wydaje się być trafna, gdy zostaje wzmocniona autorytetem medycyny. Dlatego też postępuje proces medykalizacji innych kategorii specjalnych potrzeb edukacyjnych.

Medykalizacja różnorodnych stanów bądź problemów ludzi, będąca celem działalności ukierunkowanych na zysk przedsiębiorstw biotechnologicznych, jest możliwa dzięki manipulacjom kryteriami, granicami normy i patologii, wyolbrzymianiu zagrożeń, przekształcaniu czynników ryzyka, czy normalnych stanów biologicznych w choroby. Jednak możliwe jest to jedynie wtedy, gdy w tych procesach uczestniczy nauka (Nowakowski 2013: 14).

Cytowany autor podkreśla proces manipulowania granicami normy i patologii, wprzęgając $w$ jego uzasadnienie ukierunkowanie na zysk firm farmaceutycznych. Dociekanie przyczyn postępującej medykalizacji trudności w uczeniu się lub potrzeb edukacyjnych leży poza zainteresowaniem podjętej przeze mnie problematyki, choć stanowi interesującą tezę do szerszej refleksji. Medykalizacyjne praktyki wobec uczniów ze specjalnymi potrzebami obecne są także w klasyfikacjach kryteriów diagnostycznych. W klasyfikacji Amerykańskiego Towarzystwa 
Psychiatrycznego (DSM-5) uczniów ze specyficznymi trudnościami w uczeniu się lokuje się $\mathrm{w}$ rozdziale poświęconym specyficznym zaburzeniom uczenia się (Gałecki, Święcicki, red., 2015: 33), używając do kodowania tych trudności określeń: z upośledzeniem czytania, z upośledzeniem umiejętności pisania, z upośledzeniem umiejętności liczenia. Klasyfikacja DSM stanowi także w Polsce istotne źródło wiedzy o istocie trudności w uczeniu się (Bogdanowicz 2006). W efekcie medykalizacyjnych praktyk stosuje się wobec dzieci ze specjalnymi potrzebami edukacyjnymi leczenie farmakologiczne, dla przykładu lek o nazwie Concerta wykorzystuje się $\mathrm{w}$ leczeniu zespołu nadpobudliwości ruchowej z zaburzeniem koncentracji uwagi, a lek o nazwie Piracetam - we wspomaganiu trudności dyslektycznych. Oba te leki na stronach internetowych Informacji Leków posiadają rekomendacje dla leczenia dzieci w podanych obszarach. Zatem, podsumowując, można sugerować, że pomimo zaleceń indywidualizacji i dostosowania kształcenia szkolnego do potrzeb uczniów ze specjalnymi potrzebami edukacyjnymi, diagnoza okazuje się kolejną formą separowania naznaczonych diagnozą, poddanych farmakoterapii uczniów od ich kolegów mieszczących się w normie.

Zamiast zakończenia chciałabym spojrzeć na zagadnienie specjalnych potrzeb edukacyjnych z perspektywy towarzyszącej wielu podejmowanym w świecie inicjatywom rozszerzania edukacji. Zarówno główny program edukacyjny UNESCO (Education for All), jak też przywoływane wcześniej dokumenty (deklaracja $z$ Salamanki) czy raport UNESCO (Delors, red., 1998) opracowany przez Jacques’a Delorsa, podkreślają znaczenie powszechnej edukacji dla przyszłości. Możliwość uczestniczenia w publicznym, bezpłatnym szkolnictwie staje się istotą wysiłków rządów i organizacji społecznych. Edukacja oparta na czterech filarach uczenia się: uczyć się, aby wiedzieć, aby działać, aby żyć wspólnie, aby być (Delors, red.: 1998) jest wyzwaniem dla XXI wieku. Wśród tych znaczących na poziomie światowym dokumentów podkreśla się powszechny dostęp do dobrej, niedyskryminującej edukacji. W prezentowanym tekście podjęłam próbę analizy sytuacji edukacyjnej, trudności w uczeniu się i form pomocy oraz ich efektywności w odniesieniu do uczniów ze specjalnymi potrzebami edukacyjnymi. Wieloletnia praca terapeutyczna z tą grupą dzieci, a także znaczenie podjętego zagadnienia dla edukacji stanowią uzasadnienie przedstawionej argumentacji.

\section{Literatura}

Ball S.J., 1999, Foucault i edukacja: dyscypliny i wiedza, tłum. K. Kwaśniewicz, Kraków: Impuls.

Bogdanowicz M., 2006, Specyficzne trudności w czytaniu i pisaniu [w:] Dysleksja rozwojowa. Perspektywa psychologiczna, red. G. Krasowicz-Kupis, Gdańsk: Harmonia.

Bogdanowicz M., Adryjanek A., 2004, Uczeń z dysleksja w szkole, Gdynia: Operon.

Chrzanowska I., 2015, Pedagogika specjalna. Od tradycji do współczesności, Kraków:

Impuls. 
Delors J. (red.), 1998, Edukacja - jest w niej ukryty skarb: raport dla UNESCO Międzynarodowej Komisji do spraw Edukacji dla XXI wieku; tłum. W. Rabczuk, Warszawa: Stowarzyszenie Oświatowców Polskich, Wydawnictwa UNESCO.

Dyrda J., 2009, Norma szkolna i jej pedagogiczne skutki [w:] Pedagogika wczesnoszkolna - dyskursy, problemy, rozwiązania, red. D. Klus-Stańska, M. Szczepska-Pustkowska, Warszawa: Wydawnictwo Akademickie i Profesjonalne.

Foucault M., 2009, Nadzorować i karać. Narodziny więzienia, tłum. T. Komendant, Warszawa: Aletheia.

Gałecki P., Święcicki Ł. (red.), 2015, Kryteria Diagnostyczne z DSM-5. DESK REfFERENCE, tłum. S.P. Krawczyk, Wrocław: Edra Urban \& Partner.

Gardner H., Kornhaber M., Wake W., 2001, Inteligencja. Wielorakie perspektywy, red. E. Nęcka, tłum. M. Groborz, M. Śmieja, Warszawa: Wydawnictwa Szkolne i Pedagogiczne.

Jacyno M., 2007, Kultura indywidualizmu, Warszawa: Wydawnictwo Naukowe PWN.

Klinkosz W., 2013, Wybrane aspekty badań nad uzdolnionymi uczniami niepetnosprawnymi [w:] Psychologia zdolności. Współczesne kierunki badań, red. A. Sękowski, Warszawa: Wydawnictwo Naukowe PWN.

Nowakowski M., 2013, Medykalizacja we współczesnym społeczeństwie. Studium literatury przedmiotu, praca doktorska obroniona na Wydziale Filozofii i Socjologii Uniwersytetu Marii Curie-Skłodowskiej w Lublinie, www.umcs.pl/pl/szukaj-redirect,51763.html. [dostęp: 8.12.2017].

Obuchowska I. (red.), 1991, Dziecko niepełnosprawne w rodzinie, Warszawa: Wydawnictwa Szkolne i Pedagogiczne.

Olechowska A., 2016, Specjalne potrzeby edukacyjne, Warszawa: Wydawnictwo Naukowe PWN. Rimm S.B., 1994, Bariery szkolnej kariery. Dlaczego dzieci zdolne maja słabe stopnie, tłum. D. Ekiert-Grabowska, Warszawa: Wydawnictwa Szkolne i Pedagogiczne.

Robinson K., 2010, Oblicza umysłu. Ucząc się kreatywności, tłum. A. Baj, Kraków: Element.

\title{
Dokumenty
}

Deklaracja $z$ Salamanki oraz wytyczne dla działań w zakresie specjalnych potrzeb edukacyjnych przyjęte przez światowa konferencję dotyczaca specjalnych potrzeb edukacyjnych: dostęp i jakość, 1994, Salamanka, Hiszpania 7-10 czerwca 1994 r., UNESCO, http:// www.m.eurosprawni.org/www.eurosprawni.org/pl/prawo/314-deklaracja-z-salamanki-oraz-wytyczne-dla-dzialan-w-zakresie-specjalnych-potrzeb-edukacyjnych.html.

Ustawa z dnia 7 września 1991 r. o systemie oświaty (tekst jedn.: Dz. U. z 2016 r., poz. 1943). Rozporządzenie Ministra Edukacji Narodowej z dnia 30 kwietnia 2013 r. w sprawie udzielania pomocy psychologiczno-pedagogicznej w publicznych przedszkolach, szkołach i placówkach (Dz. U. z 2017 r., poz. 1643).

\begin{abstract}
Abstrakt
W artykule podejmuję problematykę uczniów ze specjalnymi potrzebami edukacyjnymi, których funkcjonowanie w publicznych placówkach edukacyjnych (przedszkolach, szkołach i innych kształcących instytucjach) regulowane jest podpisanymi przez Polskę
\end{abstract}


dokumentami międzynarodowymi i rozporządzeniami Ministra Edukacji Narodowej. Problem kształcenia uczniów ze specjalnymi potrzebami dotyczy zarówno formalnej i organizacyjnej strony działań pomocowych i zajęć specjalistycznych, jak i krytycznego namysłu nad podporządkowaniem ich z jednej strony oczekiwaniom instytucjonalnej szkoły, a z drugiej - wyodrębnianiem ich odmiennej indywidualności. Ambiwalencja funkcjonowania opisanej grupy uczniów polega na korzystaniu z pewnych przywilejów, orzeczeń i opinii, a jednocześnie napiętnowaniu niespełnianiem norm i oczekiwań formułowanych w obszarze instytucji.

\section{Słowa kluczowe}

specjalne potrzeby edukacyjne, normy szkolne, indywidualizacja w nauczaniu, medykalizacja

\section{Summary}

Educational pressure of norms. Critical notes on the margin of work with children of special educational needs

The text discusses the matter of pupils with special educational needs, whose ability to function in public educational institutions (kindergartens, schools etc.) is governed by the international documents and regulations of the Minister of National Education. The problem of educating students with special needs concerns both the formal and organizational sides of support and specially organized activities, as well as the critical reflection of subordinating them to the expectations of the institutional school, and their distinct individuality. The ambivalence the described group of students ability to function is based on the existence of certain privileges and opinions in the context of stigmatizing them and their possible failure to meet standards and expectations formulated within the institution.

\section{Keywords}

special educational needs, schooling standards, individualization in teaching, medicalization 